\title{
Glikopirróniummal kezelt középsúlyos és súlyos krónikus obstruktív tüdőbetegek állapotának kérdőíves értékelése valós körülmények között
}

\author{
AMULET-pizsgálat
}

\author{
Tamási Lilla dr. ${ }^{1}$ - Speer Gábor dr. ${ }^{2,3}$ - az AMULET vizsgálóorvosai ${ }^{*}$ \\ ${ }^{1}$ Semmelweis Egyetem, Általános Orvostudományi Kar, Pulmonológiai Klinika, Budapest \\ ${ }^{2}$ Biatorbágyi Egészségügyi Központ, Endokrinológiai Ambulancia, Biatorbágy \\ ${ }^{3}$ Artmedus, Budapest
}

\begin{abstract}
Bevezetés: A krónikus obstruktív tüdőbetegség (COPD) sok szervrendszert érint, ezért a légúti áramlás korlátozottságának mértéke önmagában nem tükrözi a COPD teljes betegségterhét. Magyarországon nincsenek a járóbetegellátásban alkalmazott COPD-kérdőívekról országos adatok, így arról sem, hogy a betegek mennyire találják könnyúnek vagy nehéznek a kitöltést.

Célkitüzés és módszer: A vizsgálat célkitűzése az egészségi állapotra vonatkozó, beteg által kitöltött, irányelvek javasolta kérdő́vek (CCQ, CAT, mMRC, EQ-5D-5L) eredményeinek értékelése olyan COPD-s betegeknél, akik a mindennapos betegellátásban, 16 hetes kezelési szakaszban glikopirrónium-bromid-terápiát kaptak (korábban terápiában nem részesültek, vagy kiegészítő kombinációban más hörgőtágítókkal kapták, vagy váltás történt egyéb terápiáról). A vizsgálat nyílt elrendezésú, multicentrikus, beavatkozással nem járó, megfigyeléses volt.

Eredmények: A vizsgálatba vont 527 beteg átlagéletkora 63,8 $\pm 9,64$ év, az átlagos $\mathrm{FEV}_{1} 59,8 \pm 15,12 \%$ volt. Az elsó és az utolsó vizit között, mindhárom kezelési csoportban, klinikailag jelentősen csökkentek a CCQ-átlagpontszámok, az összes CCQ-alpontszám, a CAT- és az mMRC-pontszámok, növekedtek ugyanakkor az EQ-5D-5L- és a VASpontszámok. A vizsgálók szerint a CAT-teszt jobban tükrözte a betegek állapotát $(84,7 \%)$, mint a CCQ vagy az mMRC. A betegek szerint is a CAT-teszt a legegyszerúbb és a legkönnyebben érthető $(83,2 \%)$. Az utolsó viziten szignifikáns különbség volt a CCQ- és a CAT- $\left(\mathrm{r}_{\mathrm{s}}=0,711, \mathrm{p}<0,001\right)$, a CCQ- és az mMRC- $\left(\mathrm{r}_{\mathrm{s}}=0,524, \mathrm{p}<0,001\right)$, illetve a CAT- és az mMRC- $\left(\mathrm{r}_{\mathrm{s}}=0,475, \mathrm{p}<0,001\right)$ pontszámok között.

Következtetés: Eredményeink azt igazolták, hogy a CAT-teszt a legkönnyebben érthető a betegeknek, és a vizsgálóorvosok szerint is a CAT tükrözte a legjobban betegeik állapotát, így a CAT-teszt túnik a legígéretesebb eszköznek a COPD tüneteinek értékelésében.

Orv Hetil. 2020; 161(8): 295-305.
\end{abstract}

Kulcsszavak: krónikus obstruktív légúti betegség, glikopirrónium-bromid, életminőség, betegek egészségértékelése, valós körülmények

Assessment of patient-reported outcomes by questionnaires in patients with Moderate and severe chronic obstructive pulmonary disease treated with glycopyrroniUm in the reaL lifE setTing in Hungary (AMULET)

Introduction: Chronic obstructive pulmonary disease (COPD) is a multifactorial disorder, therefore, airflow limitation alone does not reflect the full burden of COPD. In Hungary, no national data are available yet about the results obtained with the different COPD questionnaires in daily patient care, and about difficulties of questionnaires for patients.

*Az AMULET vizsgálóorvosai: Dr. Orlovszki Viktória, Dr. Szabó Csilla, Dr. Tót Éva, Dr. Füleki Margit, Dr. Szántó Judit, Dr. Varga Ágnes, Dr. Lovász Orsolya, Dr. Magyar Zoltán, Dr. Barsai Andrea, Dr. Tárnok Ildikó, Dr. Szabó Gyöngyi, Dr. Popa Nikolett, Dr. Puskás Emese, Dr. Schlezák Judit, Dr. Jakoob Maha, Dr. Vidák Zsolt, Dr. Rakvács Marianna, Dr. Bartha Anna, Dr. Czompó Márta, Dr. Vecsey Zsuzsanna, Dr. Fónay Károly, Dr. Hajdu Krisztina, Dr. Unger Erika, Dr. Juhász Tibor, Dr. Bende Zoltán, Dr. Hangonyi Csilla, Dr. Mészáros Imre, Dr. Farkas Éva, Dr. Jancsikin Ljubomir, Dr. Stifter Aranka, Dr. Makk László, Dr. Vecsey Erika, Dr. Frank Emil, Dr. Kiss Gabriella, Dr. Csánky Eszter, Dr. Keszthelyi Réka, Dr. Kukuly Miklós, Dr. Egri Magdolna, Dr. Szabó Márta, Dr. Budai Gabriella 
Aim and method: The aim of the study was to evaluate patient-reported outcomes with guideline-suggested questionnaires (CCQ, CAT, mMRC, EQ-5D-5L) in patients treated with glycopyrronium-bromide (therapy naïve, addon combination or switch from another therapy) in the real life setting during 16 weeks treatment. This study was open-label, multi-centre, non-interventional, observational.

Results: 527 patients were enrolled in the study (mean age: $63.8 \pm 9.64$ years, mean $\mathrm{FEV}_{1}: 59.8 \pm 15.12 \%$ ). In all of the groups, the CCQ mean scores, all of the CCQ subscores, CAT and mMRC scores significantly decreased from visit 1 to visit 3. The EQ-5D-5L index and VAS scores increased significantly between visits. According to investigators' opinion, the CAT test reflects the patient's condition better (84.7\%) than CCQ or mMRC; also, from the patient's point of view, CAT was simpler and easier to understand (83.2\%). There was a positive, statistically significant correlation between CCQ and CAT $\left(\mathrm{r}_{\mathrm{s}}=0.71 \mathrm{l}, \mathrm{p}<0.001\right)$, between CCQ and mMRC $\left(\mathrm{r}_{\mathrm{s}}=0.524, \mathrm{p}<0.001\right)$ and between CAT and mMRC scores at visit $3\left(\mathrm{r}_{\mathrm{s}}=0.475, \mathrm{p}<0.001\right)$.

Conclusion: Our results suggest that the CAT test may be simpler and easier to understand for patients. Also, according to investigators' opinion, CAT reflects the patient's condition better, so CAT appears to be the most promising tool in COPD evaluation.

Keywords: chronic obstructive pulmonary disease, glycopyrronium-bromide, quality of life, patient-reported outcome, real life

Tamási L, Speer G, Investigators of the AMULET study. [Assessment of patient-reported outcomes by questionnaires in patients with Moderate and severe chronic obstructive pulmonary disease treated with glycopyrroniUm in the reaL lifE setTing in Hungary (AMULET)]. Orv Hetil. 2020; 161(8): 295-305.

(Beérkezett: 2019. október 14.; elfogadva: 2019. november 11.)

\begin{abstract}
Rövidítések
CAT $=($ COPD Assessment Test $)$ COPD Állapotfelmérő Teszt; $\mathrm{CCQ}=($ Clinical COPD Questionnaire $)$ Klinikai COPD Kérdő́v; $\mathrm{CDMS}=($ clinical data management system $)$ klinikai adatkezelő rendszer; COPD $=($ chronic obstructive pulmonary disease) krónikus obstruktív tüdőbetegség; eCRF = (electronic case report form) elektronikus egyéni vizsgálati adatlap; EQ-5D-5L = (EuroQol-5-dimension 5-level questionnaire) EuroQol 5 dimenziós, 5 szintes Egészségi Állapot Kérdőív; EuroQol $=$ (European quality of life $)$ európai életminőség; $\mathrm{FEV}_{1}=$ (forced expiratory volume in 1 second) forszírozott exspirációs volumen 1 másodperc alatt; $\mathrm{FVC}=$ (forced vital capacity) erőltetett kilégzési vitálkapacitás; GLY = glikopirrónium-bromid; GOLD = (Global Initiative for Chronic Obstructive Lung Disease) a COPD ellen küzdő globális kezdeményezés; HRQoL = (health-related quality of life) egészséggel összefüggő életminőség; LABA = (long-acting beta $_{2}$ agonists) hosszú hatású inhalációs béta ${ }_{2}$-agonisták; LAMA = (long-acting muscarinic antagonists) hosszú hatású muszkarinantagonisták; mMRC $=$ (modified MRC questionnaire) módosított MRC-dyspnoekérdőív; $\mathrm{MRC}=$ (Medical Research Council) Orvosi Kutatások Tanácsa (Nagy-Britannia) $; \mathrm{PRO}=$ (patient-related outcome) beteg által jelentett eredmény; VAS = (visual analogue scale) vizuális analóg skála
\end{abstract}

A krónikus obstruktív tüdőbetegség (COPD) multifaktoriális betegség; akárcsak a tüdőben, szerkezeti és funkcionális változások jellemzik egyéb szervekben is [1-3]. A légúti áramlás korlátozottságának mértéke önmagában nem tükrözi a COPD teljes betegségterhét, továbbá megkérdőjelezhető a $\mathrm{FEV}_{1}$ (forszírozott exspirációs volumen 1 másodperc alatt) és a betegvisszajelzés (a betegek egészségértékelése) közötti összefüggés (dyspnoe, a fizikai terhelhetőség csökkenése, valamint az egészségi állapottal kapcsolatos életminőség) [4-6]. A COPD-s betegek kezelésének fó célja a betegek panaszaira való összpontosítás, a tünetek csökkentése mellett az exacerbatiók megelőzése, valamint a fizikai terhelhetőség és az életminőség javítása $[1,7]$. A tünetek tükrözik a COPD-s betegek állapotát, jelenlétük így befolyásolja a betegek jóllétét. Úgy tû́nik, hogy a COPD-s tünetek szorosabb összefüggést mutatnak az életminőséggel, mint maga a légúti obstrukció mértéke, ami arra utal, hogy az életminőséget jobban befolyásolják, mint a $\mathrm{FEV}_{1}$-ben bekövetkezô változások.

E felismerések odavezettek, hogy a jelenlegi nemzetközi irányelv (GOLD [Global Initiative for Chronic Obstructive Lung Disease] 2019) a betegek állapotának értékelése során a tüneteket ugyanolyan fontosnak ítéli meg, mint a légzésfunkciót vagy az exacerbatio rizikóját. A legújabb GOLD-ajánlás különböző kérdőívek alkalmazását javasolja a tünetesség mértékének értékelésére [1]. Bármelyik használható a mindennapi betegellátásban, ezek: modified Medical Research Council questionnaire (mMRC), COPD Assessment Test (CAT), Clinical COPD Questionnaire (CCQ) és az EuroQol-5-dimension 5-level questionnaire (EQ-5D-5L) [8].

A jelen, beavatkozással nem járó, megfigyeléses vizsgálat célja az volt, hogy értékeljük a COPD-s betegek által adott visszajelzéseket az 50 mikrogramm glikopirrónium-bromid (GLY) napi egyszeri, Breezhaler ${ }^{\circledR}$ segítségével történő alkalmazása mellett valós körülmények között, egy 16 hetes kezelési szakasz során. A COPD-vel kapcsolatos egészségi állapotot a CCQ, a CAT és az mMRC segítségével értékeltük 3 GLY-mal kezelt betegcsoportban (monoterápiában, egyéb hörgőtágítókkal kombinációban alkalmazva, illetve LABA- vagy LAMA- 
terápiáról történő váltás esetén). A 3 kezelési csoportban az életminőséget is értékeltük az EQ-5D-5L-kérdőívvel. A vizsgálat fó célkitüzése tehát a betegek visszajelzésének értékelése volt a GLY-mal kezelt COPD-s betegek körében, valós körülmények között. Az elsődleges változó a CCQ-összpontszám átlagos változása volt a GLY-ot alkalmazó 3 betegcsoportban a 16 hetes kezelési periódus során. A másodlagos célkitüzések között szerepelt a COPD klinikai kontrolláltságának megítélése a CAT és az mMRC alkalmazásával a GLY-kezelés mellett. A CCQ-összpontszám, valamint a CAT- és az mMRCösszpontszám közötti összefüggést szintén vizsgáltuk. Értékeltük az EQ-5D-5L-kérdőív által mért életminőséget is a 3 kezelési csoportban, valamint a betegek/orvosok véleményét/észrevételeit az alkalmazott kérdőívek használatával kapcsolatban. A vizsgálatban értékeltük a nemkívánatos eseményeket is.

\section{Betegek és módszer}

\section{A vizsgálat elvendezése}

$\mathrm{Az}$ 1. kezelési csoportba a korábban kezelésben nem részesült betegek kerültek (betegszám: 372). A 2. csoportban a GLY-ot kiegészítő terápiaként kapó betegek voltak (kivéve LAMA, betegszám: 102). A 3. csoportba pedig azon betegek kerültek, akiknél más terápiáról történt GLY-ra váltás $(\mathrm{n}=53)$.

A vizsgálat nyílt elrendezésú, multicentrikus, beavatkozással nem járó, megfigyeléses vizsgálat volt olyan COPDs betegek körében, akik megbetegedésükre GLY-kezelést kaptak 16 héten keresztül. A kezelés lehetett elsőként választott monoterápia (korábban kezelést nem kapottak, 1. csoport), első kiegészítő kezelésként elrendelt GLY egy másik, aktuálisan alkalmazott hörgőtágító mellett (2. csoport), illetve a mindennapos ellátás során másik hörgőtágítóról váltásként (váltás LABA- vagy egyéb LAMA-készítményről, 3. csoport). Az 1. vizit alkalmával a betegek kitöltötték a kérdőíveket (CCQ, CAT, mMRC, EQ-5D-5L). Ekkor dokumentáltuk a betegek demográfiai adatait, kórtörténetét, egyidejúleg alkalmazott gyógyszereit. Négyhetes kezelést követően (a 2. vizit alkalmával), valamint 16 hetes kezelést követően (3. vizit) a betegek ismét kitöltötték a kérdőíveket (1. táblázat). A tüdőgyógyász szakorvos a rutinellátásnak megfelelően értékelte a kezelést és a betegek általános egészségi állapotát. $\mathrm{A} \mathrm{FEV}_{1}$-adatok rögzítése nem volt kötelező a vizsgálatban. Azon betegek, akik bármilyen okból nem teljesítették a vizsgálatot (nem volt javulás a kezelés mellett, emiatt a kezelés módosítása vált szükségessé, nemkívánatos esemény lépett fel, vagy a beteg visszavonta beleegyezését, stb.) kizárásra kerültek a vizsgálatból, és helyettesítésük más betegekkel nem volt engedélyezett.

A GLY-ot a tüdőgyógyász írta fel a Magyarországon aktuálisan érvényes COPD-kezelési irányelveknek megfelelően, a hazai forgalombahozatali engedélyben és támogatási irányelvekben foglaltak szerint. A betegeknek
1. táblázat |A vizitek ütemterve és a vizsgálóorvos által jelentett adatok

\begin{tabular}{lccc}
\hline A vizit sorszáma & 1. & 2. & 3. \\
\hline A vizit napja & 1. nap & $\begin{array}{c}\text { 4. hét } \\
+10 \text { nap }\end{array}$ & $\begin{array}{c}\text { 16. hét } \\
+10 \text { nap }\end{array}$ \\
\hline
\end{tabular}

Betegtájékoztatás és

beleegyező nyilatkozat

\begin{tabular}{lccc}
\hline Beválasztási kritériumok & $\checkmark$ & \\
\hline Demográfiai adatok & $\checkmark$ & & \\
\hline $\begin{array}{l}\text { COPD-s kórtörténet, } \\
\text { dohányzással kapcsolatos } \\
\text { anamnézis }\end{array}$ & $\checkmark$ & $\checkmark$ & $\checkmark$ \\
\hline
\end{tabular}

\begin{tabular}{llll}
\hline Alkalmazott gyógyszerek & $\checkmark$ & $\checkmark$ & $\checkmark$ \\
\hline $\begin{array}{l}\text { Korábbi és mentőterápia- } \\
\text { ként használt COPD- } \\
\text { gyógyszer(ek) }\end{array}$ & $\checkmark$ & $\checkmark$ & $\checkmark$ \\
\hline
\end{tabular}

CCQ, CAT, mMRC

vonatkozású tájékoztatás a

betegek számára

A CCQ és a CAT kitöltése a

beteg által*

A CCQ és a CAT teljes

kitöltöttségének ellenőrzése,

az mMRC kitöltése

\begin{tabular}{lccc}
\hline Az EQ-5D-5L kitöltése & $\checkmark$ & $\checkmark$ \\
\hline $\begin{array}{l}\text { A gyógyszer(ek) módosítása } \\
\text { (ha van) }\end{array}$ & $\checkmark$ & $\checkmark$ \\
\hline $\begin{array}{l}\text { Nemkívánatos események } \\
\text { jelentése }\end{array}$ & $\checkmark$ & $\checkmark$ & $\checkmark$ \\
\hline A vizsgálat befejezése & & $\checkmark$ \\
\hline
\end{tabular}

*A 2. és a 3. vizit alkalmával először a CCQ-t és a CAT-kérdőívet kellett kitölteni minden egyéb értékelés előtt.

†Minden olyan jelentendő nemkívánatos esemény (AE) feltüntetésre került az adatlapokon, amely a vizsgálat során történt. Ezenfelül a jelentendő $\mathrm{AE}$-ket az ún. súlyos nemkívánatos esemény (SAE-) ürlapokon is jelentették a vizsgálat folyamán.

CAT = COPD Állapotfelmérő Teszt CCQ = Klinikai COPD Kérdőív; COPD = krónikus obstruktív tüdőbetegség; EQ-5D-5L = EuroQol 5 dimenziós, 5 szintes Egészségi Állapot Kérdőív; $m M R C=$ módosított MRC-dyspnoekérdóív

az 1. vizit alkalmával alá kellett írniuk a betegtájékoztató és beleegyező nyomtatványt. A bevonási időszak 15 hónap volt (2016 áprilisától 2017 júniusáig). A vizsgálatot és a vizsgálati tervet a helyi etikai bizottság és az érintett hatóság is jóváhagyta. Minden, a vizsgálatban használt kérdő́iv validált volt hazai vonatkozásban. A vizsgálók minden vizsgálati adatot elektronikusan - a Mythos CDMS elnevezésû eCRF-rendszerben - gyújtöttek, amelynek fejlesztési és üzemeltetési feladatait az AdWare Research Kft. végezte.

\section{Vizsgálati populáció}

Tünetes, középsúlyos és súlyos COPD-ben szenvedő (GOLD, 2014) férfi és nőbeteg (életkor $\geq 40$ év) vett részt a vizsgálatban. A betegek a tüdőgyógyászati járóbe- 
teg-ellátási centrumokból kerültek kiválasztásra. A részt vevő centrumokat az egész ország területérôl válogattuk ki, így reprezentálva a magyarországi COPD-s betegpopulációt. A kezelőorvosok (vizsgálók) összesen 626 olyan COPD-s beteget vontak be, akik az alkalmazási előírás szerint kaptak GLY-ot a kezelőorvos döntése és az irányelvek alapján. A beválasztási kritériumnak megfelelően a betegek aktuálisan vagy korábban dohányoztak, és dohányzási anamnézisük mértéke legalább 10 csomagév volt (például 10 csomagév $=1$ csomag $/$ nap $\times 10$ év vagy $1 / 2$ csomag/nap $\times 20$ év).

\section{Módszer}

\section{Klinikai COPD Kérdöív (CCQ - Clinical COPD Questionnaire)}

A CCQ olyan, beteg által kitöltendő kérdőív, amely a légutak klinikai állapotát, a fizikai teljesítőképesség mértékét és a mentális diszfunkciót méri. A CCQ validált kérdőív jó pszichometriai tulajdonságokkal. 10 tételből áll (mindegyikre 0 és 6 közötti pontszám adható), amelyek 3 területre oszlanak (tünetek, funkcionális állapot, mentális állapot). Az összpontszámot az egyes tételek pontszámának összeadásával, majd az összeg 10-zel történő elosztásával számítják ki (10 a tételek száma), így az összpontszám 0 és 6 közötti érték lehet, amelyen belül a magasabb pontszámok rosszabb, egészséggel kapcsolatos életminőséget jelölnek (HRQoL). A kérdőív 64 különböző nyelven érhető el a következő internetes oldalon: http://www.ccq.nl.

\section{COPD Állapotfelmérō Teszt (CAT-COPD Assessment Test)}

A CAT a COPD (köhögés, köpet, dyspnoe, mellkasfeszülés) egészségi állapotra kifejtett hatásának átfogó megítélését adja meg (http://www.catestonline.org/). Ez egy nemrég kidolgozott és validált, rövid, COPD-re specifikus kérdőív. Úgy tervezték, hogy mérje a COPD egészségi állapotra kifejtett hatását. A CAT-kérdőív arra kéri a beteget, hogy értékelje aktuális tüneteit a betegséggel kapcsolatosan. A CAT 8 tételből áll, mindegyikre 0 és 5 közötti pontszám adható, így 0 és 40 közötti összpontszámot kaphatunk, ahol a 40 pont felel meg a legrosszabbnak. A stabil COPD-s betegeket megbízhatóan meg lehet különböztetni a teszttel azoktól, akiknek exacerbatiójuk van. A $\geq 10$-es CAT-pontszám jelentős tüneti szintet jelöl (GOLD, 2014). A CAT kitöltése hozzávetőlegesen 2-3 percet vesz igénybe. A CAT nagymértékben korrelál az ún. St. George-féle légzési kérdőívvel, de a CAT-nek jelentős előnye, hogy könnyebben kitölthető. Azon túlmenően, hogy a CAT felhasználóbarát, a COPD GOLD-kategorizálására is alkalmazható.

\section{Módositott MRC-dyspnoekérdöiv (mMRC-modified Medical Research Council questionnaire)}

Az mMRC légszomjskálája öt kijelentésből áll; csaknem teljes mértékben lefedi a légzési nehezítettség teljes spektrumát, a problémamentességtől ( 0 . fokozat) a teljes légzési elégtelenségig (4. fokozat). A beteg egyedül is kitöltheti, mert a teszt érthető intstrukciókat ad arra, hogyan válassza ki azt a kifejezést, amelyik a legjobban írja le az állapotát, például „Csak megeróltető terhelésre fullad” (0. fokozat), vagy „A lakását sem tudja elhagyni a légszomj miatt” (4. fokozat). Egy kérdező segítségével is kitölthető a kérdőív úgy, hogy a kijelentéseket kérdésként teszik fel, például „Légszomj jelentkezik, ha siet vagy enyhe emelkedőn megy fel?" (1. fokozat). A pontszám az a szám, amelyik a legjobban illeszkedik a beteg állapotához. Minden kérdés a mindennapos tevékenységekre vonatkozik, és általában könnyen érthető a betegek számára. A pontszám néhány másodperc alatt kiszámolható.

\section{EuroQol 5 dimenziós, 5 szintes Egészségi Állapot Kérdőín (EQ-5D-5L-EuroQol-5-dimension 5-level questionnaire)}

Az EuroQol-5D az egészségi állapot standardizált mérésére szolgál, amelyet az EuroQol-csoport fejlesztett ki azért, hogy az egészségi állapot egyszerú, általános mérését tegyék vele lehetővé. Betegségek és kezelések széles körében alkalmazható egyszerü, leíró jellegü profilt és egyetlen indexértéket eredményez az egészségi állapot vonatkozásában, amelyet az egészségügyi ellátás klinikai és gazdasági értékelésére, valamint populációs egészségügyi felmérések céljára lehet felhasználni. Az EQ-5D-t a válaszadók által való önkitöltésre tervezték, és ideálisan alkalmazható felmérésekhez, járóbeteg-ellátó helyeken és akár közvetlen interjúk esetén. Kognitív szempontból nem megerőltető, és kitöltése csak néhány percet igényel. A válaszadóknak szánt utasítások bele vannak foglalva a kérdőívbe. Az EQ-5D-5L egy 5 szintes változat, amely lényegében 2 oldalból áll: az első az EQ-5D leíró jellegû rendszer, 5 területtel és 5 válasszal, a másik oldalon pedig az EQ vizuális analóg skála található (https:// tm-centre.org/download/article-realated/191/egeszsegi-kerdoiv-0425102613.pdf).

\section{Statisztika}

A vizsgált paraméterek típusától és számától függően a páros t-próbát vagy a Wilcoxon-próbát (nem Gauss-féle eloszlást) alkalmaztuk. A Gauss-féle eloszlást a ShapiroWilk-próbával vagy a Q-Q grafikonnal ellenőriztük. A korrelációs elemzéshez a Pearson- vagy Spearman-féle (nem Gauss-féle eloszlást) elemzést alkalmaztuk. Az elsődleges elemzést a hatásossági populáción végeztük. 
A CCQ-összpontszámban bekövetkező átlagos változást a páros t-próbával vagy a Wilcoxon-próbával (nem Gauss-féle eloszlás) teszteltük. Az összpontszámban bekövetkező átlagos változást a kezelési alcsoportokban is teszteltük. Az elsődleges kimenetel vonatkozásában az elsőfajú hiba kockázatát 5\%-ra állítottuk (ami p<0,05 szignifikanciaszintnek felel meg). A másodlagos elemzést a hatásossági populáción végeztük. A korrelációs elemzéshez a Pearson- vagy Spearman-féle (nem Gauss-féle eloszlást) elemzést alkalmaztuk. Minden próbához az alfa-szint 0,05 -os ( $p$-érték<0,05) értékét tekintettük statisztikailag szignifikánsnak. A Levene-féle próbát alkalmaztuk a varianciák egyenlőségének feltételezéséhez. A statisztikai elemzést a 24-es verziószámú SPSS-ben (IBM Corporation, Armonk, NY, Amerikai Egyesült Államok [USA]) végeztük, míg a jelentés a Microsoft Word 2016-ban (Microsoft Corporation, Redmond, WA, USA) készült. A kategorikus változók tekintetében, a hiányzó adatokkal rendelkező betegek nem szerepeltek a százalékos értékek kiszámításában, hacsak másképpen nincs jelölve.

\section{Eredmények}

Vizsgálatunkba 39 centrum 626 COPD-s betegét vontuk be. A 626 betegból 527-nél állt adat rendelkezésre az elsődleges célkitűzések vonatkozásában mindhárom viziten (az eredményeket körükben értékeltük, ún. hatásossági populáció). A vizsgálatot 99 beteg hagyta abba, közülük 97 esetben jelentették az okot (két esetben az ok nem volt ismert). A vizsgálat 3 vizitból állt, az 1 . és a 2. vizit között eltelt idő mediánja 4 hét, míg az 1 . és a 3 . vizit között eltelt idő mediánja 17 hét volt. Az előre meghatározott értéktől való eltérés 1 hét volt.
2. táblázat A COPD diagnosztizálásától eltelt idő (év)

\begin{tabular}{llccc}
\hline & & $\mathrm{n}$ & Átlag & SD \\
\hline $\begin{array}{l}\text { A diagnosztizálás } \\
\text { óta eltelt idó (év) }\end{array}$ & $\begin{array}{l}\text { Terápianaiv } \\
\text { alcsoport } \\
\end{array}$ & 372 & 1,1 & 2,75 \\
& $\begin{array}{l}\text { Kiegészító terápiás } \\
\text { alcsoport }\end{array}$ & 102 & 5,2 & 4,23 \\
& $\begin{array}{l}\text { Terápiaváltásos } \\
\text { alcsoport }\end{array}$ & 53 & 6,9 & 4,73 \\
& Összesen & 527 & 2,5 & 3,97 \\
\hline
\end{tabular}

$\mathrm{COPD}$ = krónikus obstruktív tüdőbetegség; $\mathrm{SD}$ = standard deviáció

A betegek átlagéletkora 63,8 \pm 9,64 év (medián: 64 év) volt. Az 527 beteg közül 264 (50,1\%) volt férfi, míg 263 (49,9\%) nő. A betegek közül 335 (63,6\%) volt aktuálisan dohányzó, míg 192 (36,4\%) korábban volt dohányos. Az aktuálisan dohányzók aránya mindhárom kezelési csoportban hasonlónak bizonyult $(66,1 \%, 54,9 \%$, $62,3 \%)$. A COPD diagnosztizálásától eltelt átlagos idő 2,5 év volt (2. táblázat). Az átlagos $\mathrm{FEV}_{1} 59,8 \pm 15,12 \%$ volt. A hatásossági populációból (527) a betegek 98,3\%-a $(\mathrm{n}=518)$ folytatta a terápiát a vizsgálat befejezése után is.

A vizsgált (hatásossági) populációban a CCQ átlagos pontszáma szignifikánsan csökkent az 1. és a 3. vizit között (1. ábra) $(\mathrm{p}<0,05)$. A hatásossági populációban $(\mathrm{n}=$ 527 ) nemcsak a CCQ átlagos pontszáma, de az összes alpontszáma szignifikánsan csökkent az 1. és a 3. vizit között. Mindhárom kezelési csoportban (a korábban kezelést nem kapott alcsoport, a kiegészítő terápiás alcsoport és a terápiaváltásos alcsoport) a CCQ átlagos pontszáma és mindegyik alpontszám is szignifikánsan csökkent az 1. és a 3. vizit között (Wilcoxon-féle előjeles rangpróba: $\mathrm{Z}=-18,960$ [a negatív rangok alapján]).

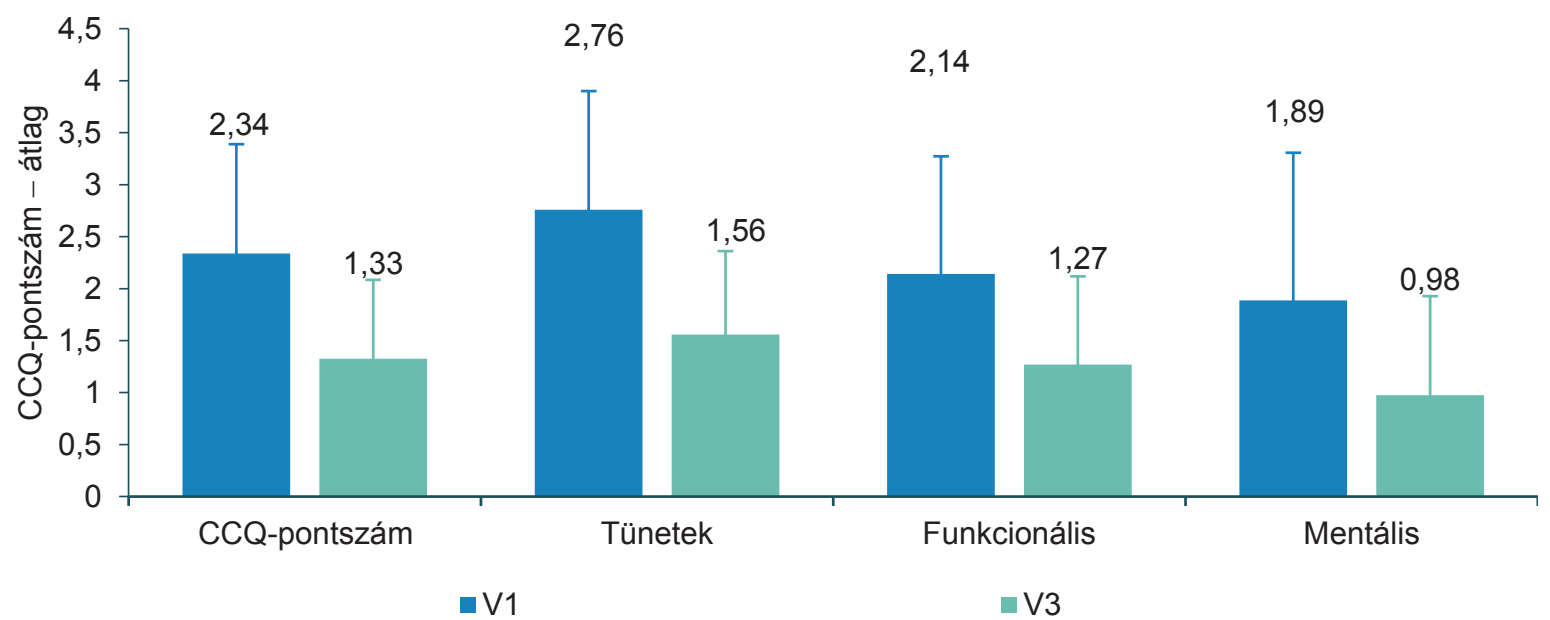

\begin{tabular}{l|l} 
1. ábra & $\begin{array}{l}\text { A CCQ-pontszámok }(\mathrm{n}=527) \\
\mathrm{CCQ}=\text { Klinikai COPD Kérdő́iv } \\
\text { Tünetek = a tünetek alpontszáma, Funkcionális = a funkcionális állapot alpontszáma, Mentális = az érzelmi állapot alpontszáma, V1 = 1. vizit, V3 = } \\
\text { 3. vizit }\end{array}$
\end{tabular} 


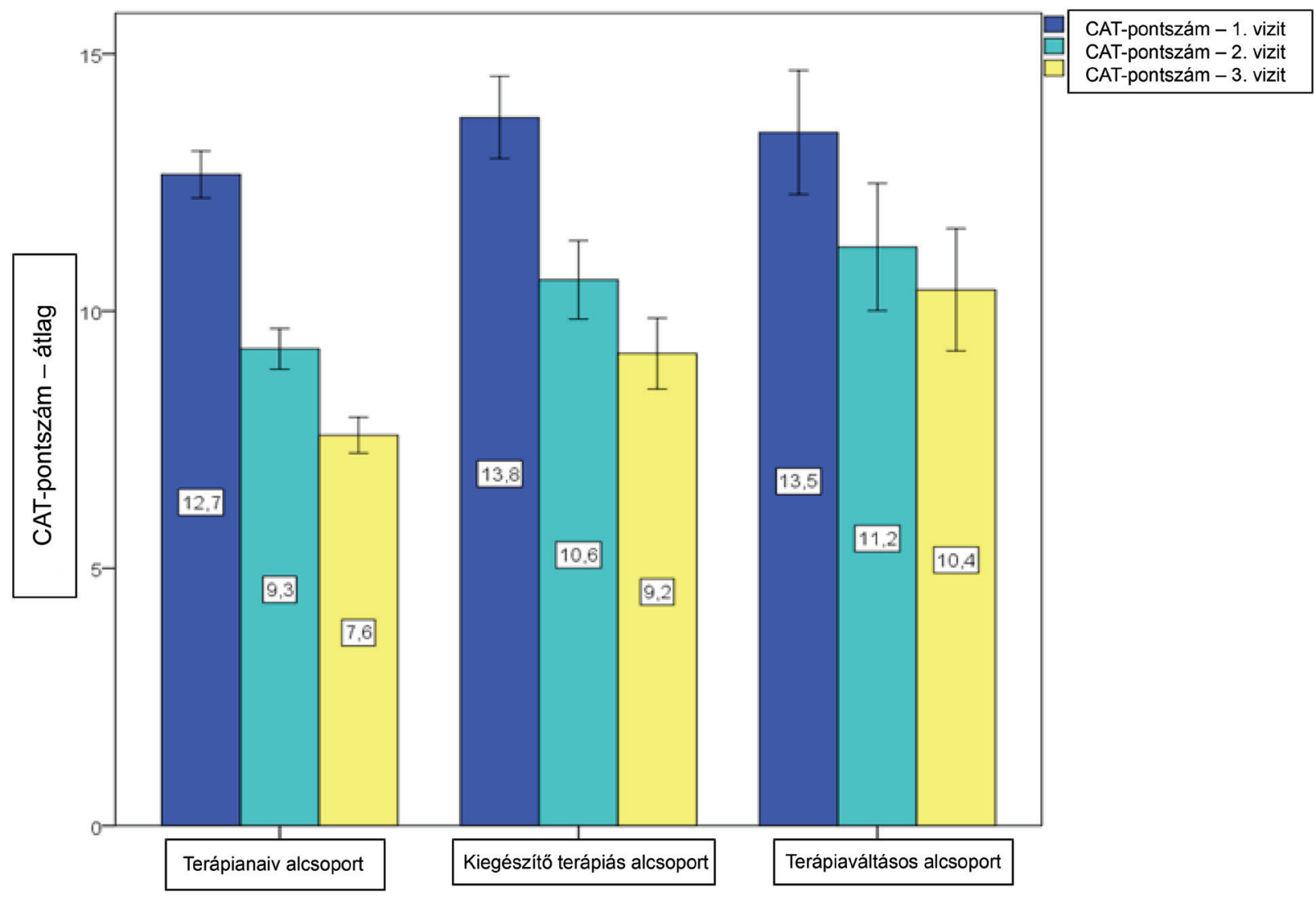

2. ábra

$$
\mid \begin{aligned}
& \text { A CAT-pontszámok (V1-V3), alcsoportonként } \\
& \text { CAT = COPD Állapotfelméró Teszt; } \mathrm{Vl}=1 \text {. vizit; V2 = 2. vizit; V3 = 3. vizit }
\end{aligned}
$$

A CAT-pontszám szintén csökkent az 1 . és a 3 . vizit között (2. ábra, 3. táblázat) $(\mathrm{p}<0,05)$. Az mMRC-pontszám ugyancsak csökkent az l. és a 3. vizit között (3. ábra, 4. táblázat) $(\mathrm{p}<0,05)$. Az EQ-5D-5L-indexpontszámok és a VAS-pontszámok növekedtek az 1 . és a 3. vizit között (4., 5. ábra és 5., 6. táblázat) $(\mathrm{p}<0,05)$.

A kérdőívek kezelhetőségével kapcsolatos véleményfelmérés azt mutatta, hogy a vizsgálóorvosok megítélése sze- rint a CAT-teszt eredményei jobban tükrözik a betegek állapotát $(84,7 \%)$. A betegek értékelése alapján is a CATteszt volt a legegyszerúbb és a legkönnyebben érthető $(83,2 \%)$. A 3. viziten pozitív, szignifikáns összefüggés volt a CCQ- és a CAT- $\left(\mathrm{r}_{\mathrm{s}}=0,711, \mathrm{p}<0,001\right)$, a CCQ- és az mMRC- $\left(r_{s}=0,524, p<0,001\right)$, illetve a CAT- és az mMRC- $\left(r_{s}=0,475, p<0,001\right)$ pontszámok között (a korrelációk szignifikánsak voltak 0,01-os szint mellett).

\begin{tabular}{|c|c|c|c|c|c|c|c|}
\hline & & $\mathrm{n}$ & Átlag & SD & $\begin{array}{l}95,0 \% \text {-os alacsony } \\
\text { CL az átlag } \\
\text { vonatkozásában }\end{array}$ & $\begin{array}{c}\text { 95,0\%-os magas } \\
\text { CL az átlag } \\
\text { vonatkozásában }\end{array}$ & Medián \\
\hline \multirow{3}{*}{$\begin{array}{l}\text { CAT-pontszám } \\
\text { - 1. vizit }\end{array}$} & Terápianaiv alcsoport & 372 & 12,7 & 4,46 & 12,2 & 13,1 & 13,0 \\
\hline & Kiegészítő terápiás alcsoport & 102 & 13,8 & 4,07 & 13,0 & 14,6 & 14,0 \\
\hline & Terápiaváltásos alcsoport & 53 & 13,5 & 4,37 & 12,3 & 14,7 & 14,0 \\
\hline \multirow{3}{*}{$\begin{array}{l}\text { CAT-pontszám } \\
-2 . \text { vizit }\end{array}$} & Terápianaiv alcsoport & 372 & 9,3 & 3,88 & 8,9 & 9,7 & 9,0 \\
\hline & Kiegészítő terápiás alcsoport & 102 & 10,6 & 3,88 & 9,8 & 11,4 & 11,0 \\
\hline & Terápiaváltásos alcsoport & 53 & 11,2 & 4,49 & 10,0 & 12,5 & 12,0 \\
\hline \multirow{3}{*}{$\begin{array}{l}\text { CAT-pontszám } \\
-3 \text {. vizit }\end{array}$} & Terápianaiv alcsoport & 372 & 7,6 & 3,40 & 7,2 & 7,9 & 7,0 \\
\hline & Kiegészítő terápiás alcsoport & 102 & 9,2 & 3,51 & 8,5 & 9,9 & 9,0 \\
\hline & Terápiaváltásos alcsoport & 53 & 10,4 & 4,32 & 9,2 & 11,6 & 11,0 \\
\hline
\end{tabular}

3. táblázat |A CAT-pontszámok (Vl-V3), alcsoportonként

$\mathrm{CAT}=\mathrm{COPD}$ Állapotfelmérő Teszt; $\mathrm{CL}=$ középső vonal; $\mathrm{SD}=$ standard deviáció; $\mathrm{Vl}=1$. vizit; $\mathrm{V} 2=2$. vizit; V3 = 3. vizit 


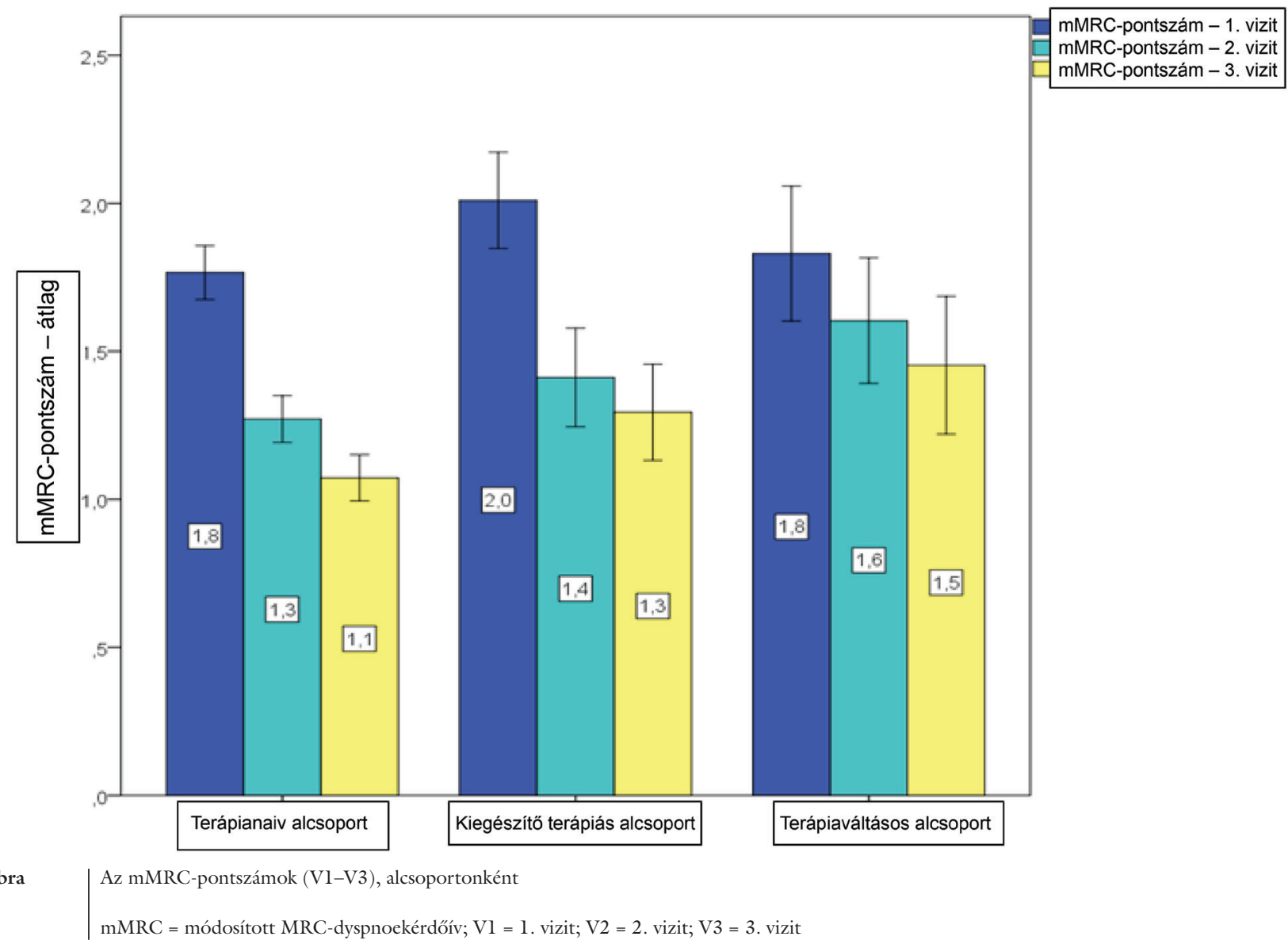

Vizsgálatunk során mindösszesen 84 nemkívánatos eseményt jelentettek, és ezek közül 7-et jelentettek súlyos nemkívánatos eseményként. 11 esetben volt gyanú arra, hogy az esemény összefügg a vizsgálati készítménynyel. 6 halálesetet rögzítettek a vizsgálat során, melyek közül a vizsgálóorvosok megítélése szerint egyik sem volt összefüggésben a vizsgálati készítménnyel. Vizsgálatunkban a leggyakoribb antikolinerg mellékhatás a szájszárazság volt, ami megfelelt a GLY alkalmazási elő́rásában foglaltaknak. A többi mellékhatás közeli egyezést mutatott a GLY biztonságossági profiljában részletezettekkel.

4. táblázat |Az mMRC-pontszámok (V1-V3), alcsoportonként

\begin{tabular}{|c|c|c|c|c|c|c|c|}
\hline & & $\mathrm{n}$ & Átlag & SD & $\begin{array}{c}\text { 95,0\%-os } \\
\text { alacsony CL } \\
\text { az átlag } \\
\text { vonatkozásában }\end{array}$ & $\begin{array}{c}\text { 95,0\%-os magas } \\
\text { CL } \\
\text { az átlag } \\
\text { vonatkozásában }\end{array}$ & Medián \\
\hline \multirow[t]{3}{*}{ mMRC-pontszám - 1. vizit } & Terápianaiv alcsoport & 372 & 1,8 & 0,89 & 1,7 & 1,9 & 2,0 \\
\hline & Kiegészítő terápiás alcsoport & 102 & 2,0 & 0,83 & 1,8 & 2,2 & 2,0 \\
\hline & Terápiaváltásos alcsoport & 53 & 1,8 & 0,83 & 1,6 & 2,1 & 2,0 \\
\hline \multirow[t]{3}{*}{ mMRC-pontszám - 2. vizit } & Terápianaiv alcsoport & 372 & 1,3 & 0,78 & 1,2 & 1,4 & 1,0 \\
\hline & Kiegészítő terápiás alcsoport & 102 & 1,4 & 0,85 & 1,2 & 1,6 & 1,0 \\
\hline & Terápiaváltásos alcsoport & 53 & 1,6 & 0,77 & 1,4 & 1,8 & 2,0 \\
\hline \multirow[t]{3}{*}{ mMRC-pontszám - 3. vizit } & Terápianaiv alcsoport & 372 & 1,1 & 0,76 & 1,0 & 1,2 & 1,0 \\
\hline & Kiegészítő terápiás alcsoport & 102 & 1,3 & 0,83 & 1,1 & 1,5 & 1,0 \\
\hline & Terápiaváltásos alcsoport & 53 & 1,5 & 0,85 & 1,2 & 1,7 & 2,0 \\
\hline
\end{tabular}

$\mathrm{CL}=$ középső vonal; $\mathrm{mMRC}=$ módosított $\mathrm{MRC}$-dyspnoekérdő́ív; $\mathrm{SD}=$ standard deviáció; $\mathrm{V} 1=1$. vizit; V2 = 2 . vizit; V3 = 3 . vizit 


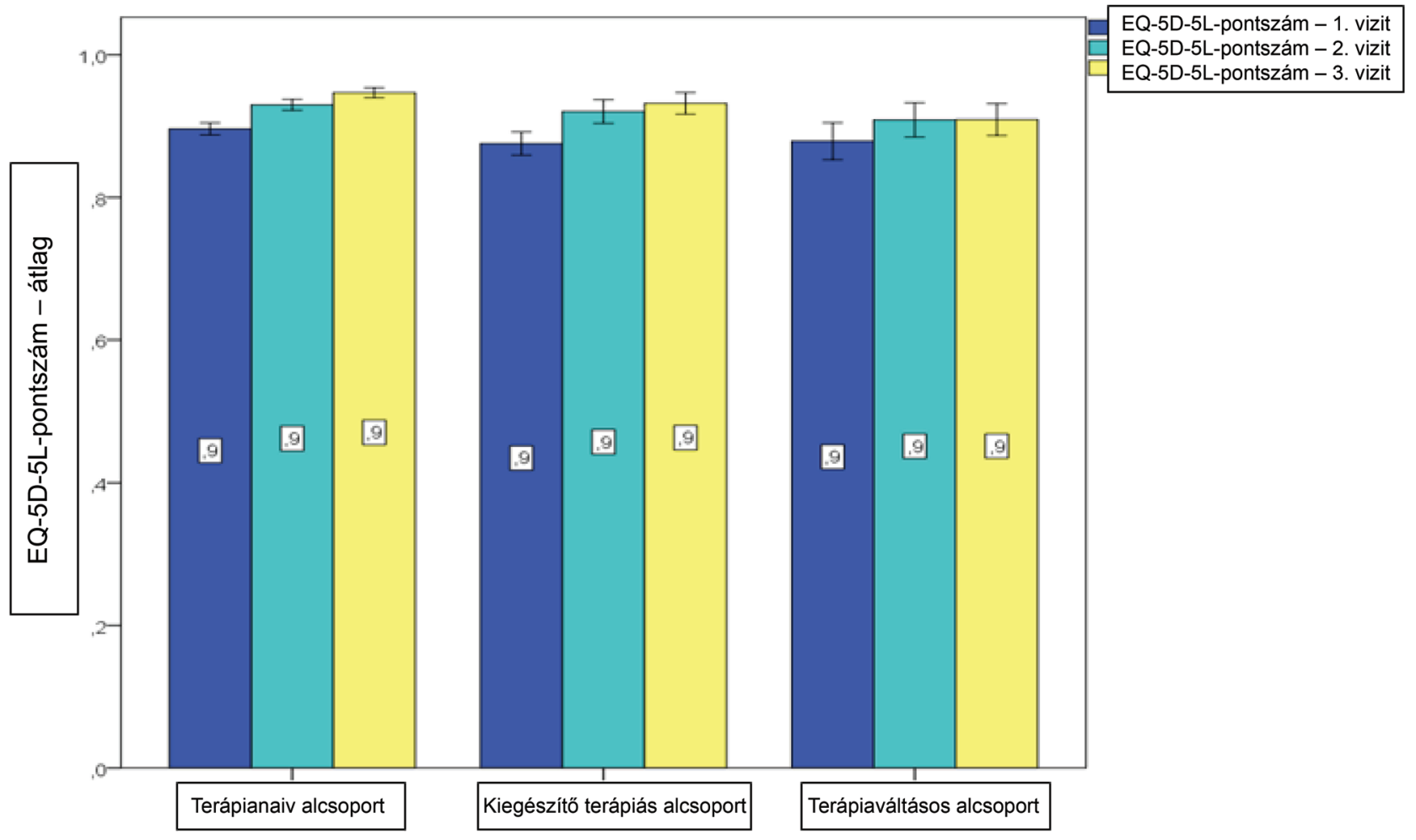

4. ábra $\quad$ Az EQ-5D-5L-index-pontszámok (V1-V3), alcsoportonként

EQ-5D-5L = EuroQol 5 dimenziós, 5 szintes Egészségi Állapot Kérdő́iv; V1 = 1. vizit; V2 = 2. vizit; V3 = 3. vizit

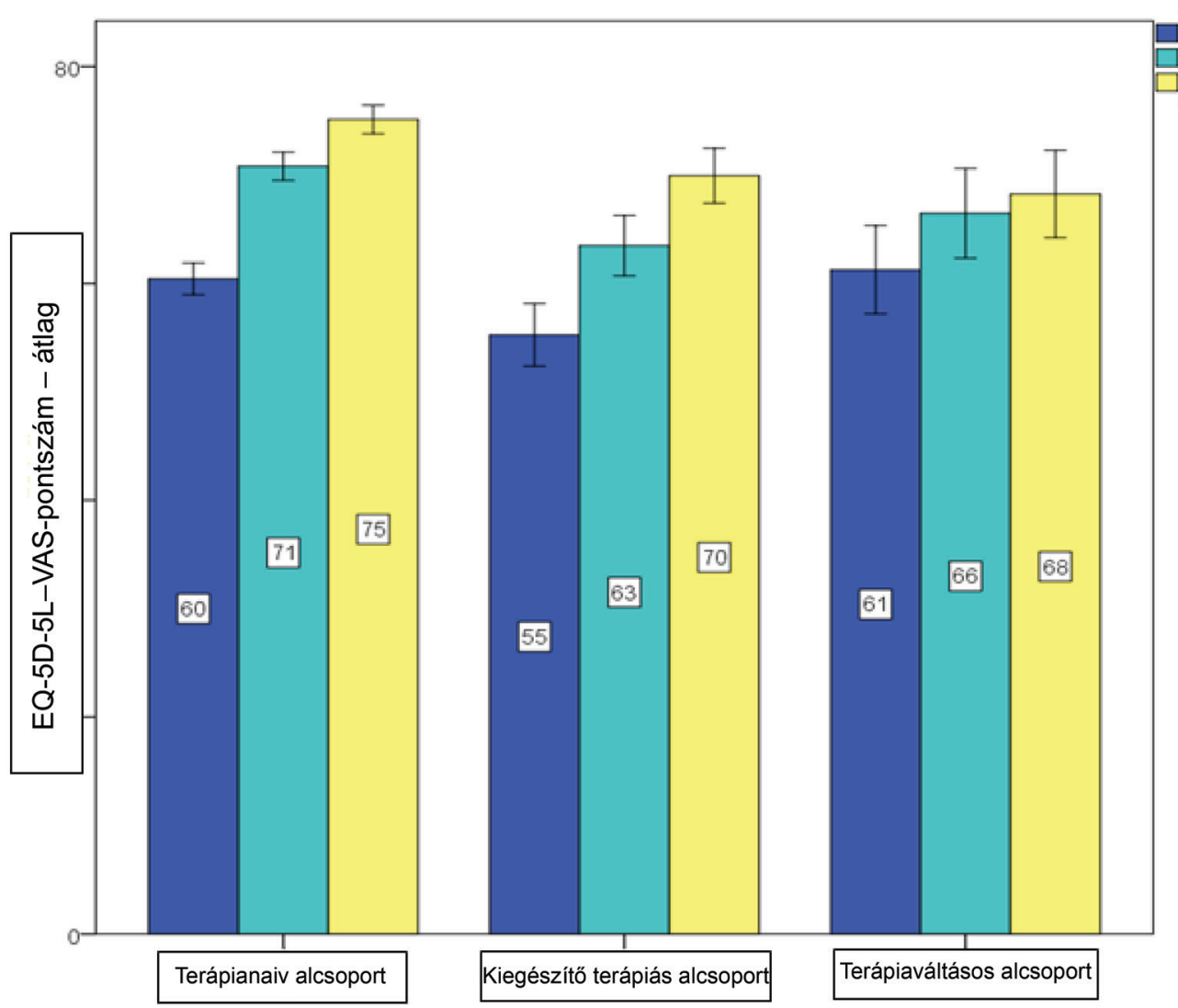

5. ábra $\quad$ Az EQ-5D-5L-VAS-pontszámok (V1-V3), alcsoportonként

EQ-5D-5L = EuroQol 5 dimenziós, 5 szintes Egészségi Állapot Kérdőív; V1 = 1. vizit; V2 = 2. vizit; V3 = 3. vizit; VAS = vizuális analóg skála 
5. táblázat |Az EQ-5D-5L-index-pontszámok (Vl-V3), alcsoportonként

\begin{tabular}{|c|c|c|c|c|c|c|c|c|}
\hline & & $\mathrm{n}$ & Hiányzik & Átlag & SD & $\begin{array}{c}\text { 95,0\%-os } \\
\text { alacsony } \\
\text { CL az } \\
\text { átlag } \\
\text { vonatko- } \\
\text { zásában }\end{array}$ & $\begin{array}{c}\text { 95,0\%-os } \\
\text { magas CL } \\
\text { az átlag } \\
\text { vonatko- } \\
\text { zásában }\end{array}$ & Medián \\
\hline \multirow{3}{*}{$\begin{array}{l}\text { EQ-5D-5L-index-pont- } \\
\text { szám - 1. vizit }\end{array}$} & Terápianaiv alcsoport & 372 & 0 & 0,896 & 0,083 & 0,888 & 0,905 & 0,909 \\
\hline & Kiegészítő terápiás alcsoport & 102 & 0 & 0,876 & 0,083 & 0,859 & 0,892 & 0,898 \\
\hline & Terápiaváltásos alcsoport & 53 & 0 & 0,879 & 0,094 & 0,853 & 0,905 & 0,909 \\
\hline \multirow{3}{*}{$\begin{array}{l}\text { EQ-5D-5L-index-pont- } \\
\text { szám - 2. vizit }\end{array}$} & Terápianaiv alcsoport & 372 & 0 & 0,930 & 0,075 & 0,922 & 0,938 & 0,918 \\
\hline & Kiegészítő terápiás alcsoport & 102 & 0 & 0,920 & 0,085 & 0,904 & 0,937 & 0,918 \\
\hline & Terápiaváltásos alcsoport & 53 & 0 & 0,909 & 0,087 & 0,885 & 0,933 & 0,918 \\
\hline \multirow{3}{*}{$\begin{array}{l}\text { EQ-5D-5L-index-pont- } \\
\text { szám - 3. vizit }\end{array}$} & Terápianaiv alcsoport & 371 & 1 & 0,947 & 0,069 & 0,940 & 0,954 & 0,999 \\
\hline & Kiegészítő terápiás alcsoport & 102 & 0 & 0,932 & 0,077 & 0,917 & 0,947 & 0,918 \\
\hline & Terápiaváltásos alcsoport & 53 & 0 & 0,909 & 0,081 & 0,887 & 0,932 & 0,918 \\
\hline
\end{tabular}

$\mathrm{CL}=$ középső vonal; EQ-5D-5L = EuroQol 5 dimenziós, 5 szintes Egészségi Állapot Kérdő́ív; $\mathrm{SD}=$ standard deviáció; V1 = 1. vizit; V2 = 2 . vizit; $\mathrm{V} 3=3$. vizit

6. táblázat | Az EQ-5D-5L-VAS-pontszámok (V1-V3), alcsoportonként

\begin{tabular}{|c|c|c|c|c|c|c|c|}
\hline & & $\mathrm{n}$ & Átlag & SD & $\begin{array}{l}\text { 95,0\%-os alacsony } \\
\text { CL az átlag } \\
\text { vonatkozásában }\end{array}$ & $\begin{array}{l}\text { 95,0\%-os magas } \\
\text { CL az átlag } \\
\text { vonatkozásában }\end{array}$ & Medián \\
\hline \multirow{3}{*}{$\begin{array}{l}\text { EQ-5D-5L-VAS-pontszám - } \\
\text { 1. vizit }\end{array}$} & Terápianaiv alcsoport & 372 & 60,4 & 14,30 & 59,0 & 61,9 & 60,0 \\
\hline & Kiegészítő terápiás alcsoport & 102 & 55,3 & 14,71 & 52,4 & 58,2 & 50,0 \\
\hline & Terápiaváltásos alcsoport & 53 & 61,3 & 14,72 & 57,2 & 65,3 & 60,0 \\
\hline \multirow{3}{*}{$\begin{array}{l}\text { EQ-5D-5L-VAS-pontszám - } \\
\text { 2. vizit }\end{array}$} & Terápianaiv alcsoport & 372 & 70,8 & 12,82 & 69,5 & 72,1 & 70,0 \\
\hline & Kiegészítő terápiás alcsoport & 102 & 63,5 & 14,12 & 60,7 & 66,3 & 60,0 \\
\hline & Terápiaváltásos alcsoport & 53 & 66,5 & 15,03 & 62,3 & 70,6 & 70,0 \\
\hline \multirow{3}{*}{$\begin{array}{l}\text { EQ-5D-5L-VAS-pontszám - } \\
\text { 3. vizit }\end{array}$} & Terápianaiv alcsoport & 372 & 75,1 & 12,93 & 73,8 & 76,4 & 75,0 \\
\hline & Kiegészítô terápiás alcsoport & 102 & 69,9 & 12,89 & 67,4 & 72,5 & 70,0 \\
\hline & Terápiaváltásos alcsoport & 53 & 68,2 & 14,64 & 64,2 & 72,3 & 70,0 \\
\hline
\end{tabular}

$\mathrm{CL}=$ középső vonal; EQ-5D-5L = EuroQol 5 dimenziós, 5 szintes Egészségi Állapot Kérdőív; SD = standard deviáció; V1 = 1. vizit; V2 = 2. vizit; $\mathrm{V} 3=3$. vizit; $\mathrm{VAS}=$ vizuális analóg skála

\section{Következtetés}

A COPD-s betegek szerteágazó tünetekkel rendelkezhetnek, amelyek jelentôsen ronthatják az egészséggel kapcsolatos életminőségüket [9]. Egyre több bizonyíték van arra, hogy a hagyományos légzésfunkciós vizsgálati eredmények önmagukban nem korrelálnak teljes mértékben a COPD-s tünetekkel és a betegségnek a betegek mindennapi életére kifejtett hatásával $[4,7,8]$, mindamellett a légzésfunkciós vizsgálat nélkülözhetetlen része a beteg vizsgálatának és a progresszió mérésének. Egyértelmúen használható biomarker hiányában a betegség progressziója bonyolítja, hogy a klinikusok hogyan értékelik a kezelés hatékonyságát [10], és a légzésfunkció itt is objektív támpontot jelent. A fentiek miatt számos, be- tegek számára készült, egészségértékelő kérdőívet (patient-related outcome, PRO) dolgoztak ki azért, hogy egyszerú és megbízható eszközt találjanak a mindennapos klinikai gyakorlat számára [11]. A kérdőívek - amelyeket a betegek közvetlenül, mások ráhatása nélkül töltenek ki - tartalmazzák a vezető tüneteket (dyspnoe, köhögés, fájdalom, kimerültség), a fellángolások gyakoriságát és az egészségi állapottal kapcsolatos elégedettséget, valamint a betegség átfogó hatásait (például munkaképesség) [12-14]. A kérdőívek a betegek álláspontját mutatják be, számszerúsítve annak mértékét, hogy a betegség milyen élettani hatást gyakorol az egészségi állapotra és funkciókra. A PRO Európai Gyógyszerügynökség által használt formális meghatározása a következő: „Bármilyen olyan kimenetel, amelyet a páciens közvetle- 
nül önmaga értékel, és amelynek alapjait a páciens a betegséggel és annak kezelésével/kezeléseivel kapcsolatos saját észlelései képezik.” A kérdőívek pontszámának időszakos értékelése a terápiák hatékonyságának megítélésére alkalmazható.

A COPD kezelésére vonatkozó GOLD-irányelv kifejezetten ajánlja kérdőívek alkalmazását mind a dokumentált, mind a nem dokumentált exacerbatiók rögzítésére, a tünetek értékelésére és a beteg számára is fontos változások rögzítésére [1, 7]. A GOLD 2019. évi irányelveiben javasolt COPD-osztályozásban fó szereppel bírnak a beteg tünetei és a jövőbeli kockázatok értékelése [1]. A tünetek tükrözik a COPD-s betegek által elszenvedett napi terhet, s ténylegesen befolyásolják a betegek jólétét. A jelen vizsgálatban a GOLD-stratégiában és a helyi irányelvekben foglaltaknak megfelelően a betegek által kitöltött mMRC-, CCQ-, CAT- és EQ-5D-5L-kérdőíveket alkalmaztuk magyarországi, valós körülmények között.

Eredményeink a valós körülmények között vizsgált kérdőívek előnyeire utalnak, mivel pozitív, szignifikáns korreláció volt a CCQ-, CAT- és mMRC-pontszámok között. A korreláció nem utal arra, hogy a vizsgált kérdőívek egymással felcserélhetők lennének, mivel ezek a kérdőívek jelentősen különböznek az értékelt tünetek számában, a kérdések érthetőségében és a kitölthetőség egyszerúségében [12-16, 17]. Magyarországon a járóbeteg-ellátásban gyưjtött eredmények kapcsán korábban nem voltak adatok a COPD-ben használt különbözó kérdőívekről, továbbá arról sem, hogy a betegek menynyire találják könnyứnek vagy nehéznek e kérdőívek kitöltését. Ez a vizsgálat volt az első, amelyik a magyarországi helyzetet értékelte.

A keresztmetszeti adatok azt mutatják, hogy a COPD-s betegek 27\%-ának rossz az egészséggel kapcsolatos életminősége, és ez - a légzésfunkción túl - jelentős hatással van a beteg gondozására is. Hazánkban a betegek ellenérzéssel bírnak a hasonló kérdóívekkel szemben, inkább a szakemberrel való személyes konzultációt részesítik előnyben. A klinikusnak szintén gondot jelenthet a kérdőívek kitöltetése a mindennapi gyakorlat terhei között. Ugyanakkor a COPD tüneteinek rutinszerú értékelése többek között a tünetek és azok mindennapi tevékenységekre kifejtett hatásai - validált és megbízható kérdőívek segítségével, mint például a CCQ, a CAT és az mMRC, pontosabb jelzést ad a betegség által okozott teherre. Ez érvényes a magyarországi, valós körülmények között történő beteggondozás keretei között is. Vizsgálatunkat követően a betegek 98,3\%-a $(\mathrm{n}=518)$ folytatta a GLYterápiát, ezzel validálva a felhasznált kérdőívekkel nyert valós és pozitív eredményeket.

Eredményeink azt sugallják, hogy a betegek szempontjából a CAT-teszt volt a legegyszerúbb és a legkönynyebben érthető. A vizsgálóorvosok véleménye szerint is a CAT-teszt tükrözte a legjobban a betegek állapotát. Eredményeink alátámasztják azon nemzetközi adatokat, amelyek szerint is a CAT a legígéretesebb PRO-eszköz, mert a többivel összevetve rövidebb, kitöltése kevesebb terhet jelent, így a betegek inkább ezt részesítik előnyben [18]. Ezen túlmenően vizsgálatunk során azt tapasztaltuk, hogy a CAT jól korrelál a többi kérdőívvel is. Más vizsgálatok szintén igazolták a CAT korrelációját a jelentősen hosszabb (50 tételt tartalmazó), St. George’s Respiratory Questionnaire kérdőívvel. Ennek értékelése komplex, és az egyes tételek vonatkozásában beteg által jelzett súlyozásokat is magában foglal [4]. Ezen COPD-s kérdőíveknek a rutin klinikai gyakorlatban történő meghonosítása feltétlenül szükséges, mert egyértelműen segítik a tüdőgyógyászokat abban, hogy értsék a beteg terápiával kapcsolatos adherenciáját, és azonosítsák azokat a pontokat, amelyek alapján a terápia módosításra szorul. Azt gondoljuk, ha a klinikus és a beteg egyaránt megszokja e kérdőívek alkalmazását, akkor az információátvitel jóval pontosabb, gyorsabb és hatékonyabb lesz mindkettőjüknek. Ezáltal több idő maradhat a konzultáció során tanácsadásra és egyéb fontos kérdésekre.

Vannak az eredményeink interpretációját limitáló tényezők is, amelyek megemlítendők. Először is, vizsgálatunk nyílt elrendezésű volt, valós körülmények között végezve. Evvel a hatásossági adatok nagy jelentőséggel bírnak, mert híján vannak azoknak a torzításoknak, amelyek a klasszikus randomizált és kontrollált vizsgálatok elválaszthatatlan velejárói. Bár tudományos szempontból elmaradnak a randomizált kettős vakvizsgálatoktól, az ezen típusú vizsgálatok fontosak annak megértésében, hogy az egyes módszerek vagy terápiák hogyan múködnek olyan körülmények között, amelyek jobban tükrözik a valós életbeli helyzeteket. Másodsorban, a beavatkozással nem járó vizsgálatokba bevont betegek heterogén csoportba tartoznak, mert tagjait a mindennapi klinikai gyakorlatban kezelik, és vizsgálatunk semmilyen egyéb korlátozást nem is alkalmazott, ezért a statisztikai becslés pontossága tág határok között ingadozhat (például a társbetegségek miatt). Azaz vizsgálatunk megfigyelő jellege miatt (kontrollcsoport hiányában) a klinikai kimenetel vonatkozásában az ok-okozati összefüggés értékelése módszertani kihívásokat okozhat. Tekintettel arra, hogy a betegek bevonása az orvos mindennapos klinikai gyakorlatán alapul, a bevont betegek populációjában torzítások léphetnek fel, amelyeket figyelembe kell venni az eredmények interpretálása során. A helyi klinikai gyakorlat sajátosságai miatt sem lehet a betegpopulációra vonatkozó általános következtetéseket levonni.

A COPD kezelésére jelenleg öt, elhúzódó hatástartamú gyógyszerosztály képviselői állnak rendelkezésre Magyarországon: hosszú hatású muszkarinantagonisták (LAMA), hosszú hatású béta ${ }_{2}$-agonisták (LABA), inhalációs kortikoszteroidok, foszfodiészterázgátlók és teofillinek. A GLY egy inhalációs LAMA (antikolinerg szer), napi egyszeri, fenntartó hörgőtágító kezelésre [19]. A paraszimpatikus idegek képezik a legjelentősebb, bronchoconstrictiót okozó idegi szabályozási utat a légutakban, míg a kolinerg tónus a légúti obstrukció kulcsfontosságú, reverzibilis összetevője COPD-ben. 
A GLY úgy fejti ki hatását, hogy gátolja az acetil-kolin bronchoconstrictiót kiváltó hatását a légúti simaizomsejteken, ezáltal tágítja a légutakat [20, 21]. Jelenleg korlátozottan áll rendelkezésre információ a GLY-kezelés valós, hazai körülmények közötti hatásosságáról COPDben. Eredményeink megerösítik a nemzetközi vizsgálatokból származó adatokat is, amelyek jelentős pozitív hatást igazoltak a GLY alkalmazásával az mMRC-, a CCQ-, a CAT- és az EQ-5D-5L-kérdőívvel mért, egészséggel kapcsolatos életminőség és beteggel kapcsolatos kimenetelek vonatkozásában.

A betegek értékelése szerint eredményünk azt igazolja, hogy a CAT-teszt a legegyszerúbb és a legkönnyebben érthető, sőt a vizsgálóorvosok véleménye szerint is a CAT-teszt tükrözi a legjobban a beteg állapotát. Eredményünk alapján úgy véljük, hogy a CAT tûnik a legígéretesebb PRO-nak a COPD értékelésében. Vizsgálatunk jelentősége abban rejlik, hogy információt nyújt a COPD-s kérdőívek által gyưjtött adatok hasznosságáról, összehasonlíthatóságáról, valamint az ajánlott három kérdőív súlyozott felhasználásáról a magyarországi betegek körében.

Anyagi támogatás: A közlemény megírása anyagi támogatásban nem részesült. A vizsgálatot a Novartis Hungária Kft. finanszírozta.

Szerzői munkamegosztás: T. L.: A klinikai vizsgálat tervezése, a közlemény javítása, kiegészítése, végleges korrektúra. S. G.: A klinikai vizsgálat tervezése, irodalomkutatás, az eredmények statisztikai feldolgozása, a közlemény megírása. Az AMULET vizsgálóorvosai: A klinikai vizsgálat elvégzése, az adatok gyưjtése. A cikk végleges változatát valamennyi szerző elolvasta és jóváhagyta.

Érdekeltségek: A szerzőknek nincsenek érdekeltségeik.

\section{Köszönetnyilvánítás}

A szerzők köszönetüket fejezik ki a vizsgálatban részt vevő betegeknek és a részt vevő vizsgálócentrumok személyzetének.

\section{Irodalom}

[1] GOLD 2019. Global Initiative for Chronic Obstructive Lung Disease, Fontana, WI. Available from: https://goldcopd.org/ [accessed: November 11, 2019].

[2] Fekete M, Pongor V, Fehér Á, et al. Relationship of chronic obstructive pulmonary disease and nutritional status - clinical observations. [Krónikus légzőszervi betegek tápláltsági állapotának vizsgálata - klinikai megfigyelések.] Orv Hetil. 2019; 160: 908 913. [Hungarian]

[3] Bán Á, Németh ZF, Szauter A, et al. Prevalence and severity of chronic parodontitis and oral mucosal lesions in chronic obstructive lung disease. [A krónikus parodontitis, illetve szájnyálkahártya-laesiók előfordulása és súlyossága krónikus obstruktív tüdőbetegségben.] Orv Hetil. 2018; 159: 831-836. [Hungarian]
[4] Jones P, Miravitlles M, van der Molen T, et al. Beyond $\mathrm{FEV}_{1}$ in COPD: a review of patient-reported outcomes and their measurement. Int J Chron Obstruct Pulmon Dis. 2012; 7: 697-709.

[5] Oga T, Nishimura K, Tsukino M, et al. Longitudinal deteriorations in patient reported outcomes in patients with COPD. Respir Med. 2007; 101: 146-153.

[6] Donohue JF, Jones PW, Bartels C, et al. Correlations between $\mathrm{FEV}_{1}$ and patient-reported outcomes: a pooled analysis of 23 clinical trials in patients with chronic obstructive pulmonary disease. Pulm Pharmacol Ther. 2018; 49: 11-19.

[7] Mackay AJ, Kostikas K, Murray L, et al. Patient-reported outcomes for the detection, quantification and evaluation of chronic obstructive pulmonary disease exacerbations. Am J Respir Crit Care Med. 2018; 198: 730-738.

[8] Westwood M, Bourbeau J, Jones PW, et al. Relationship between $\mathrm{FEV}_{1}$ change and patient-reported outcomes in randomised trials of inhaled bronchodilators for stable COPD: a systematic review. Respir Res. 2011; 12: 40.

[9] Yawn BP, Kim V. Treatment options for stable chronic obstructive pulmonary disease: current recommendations and unmet needs. Cleve Clin J Med. 2018; 85(2 Suppl 1): S28-S37.

[10] Gonçalves I, Guimarães MJ, van Zeller M, et al. Clinical and molecular markers in COPD. Pulmonology 2018; 24: 250-259.

[11] Cazzola M, Hanania NA, MacNee W, et al. A review of the most common patient-reported outcomes in COPD - revisiting current knowledge and estimating future challenges. Int J Chron Obstruct Pulmon Dis. 2015; 10: 725-738.

[12] Lee SD, Huang MS, Kang J, et al. The COPD assessment test (CAT) assists prediction of COPD exacerbations in high-risk patients. Respir Med. 2014; 108: 600-608.

[13] Perez T, Burgel PR, Paillasseur JL, et al. Modified Medical Research Council scale vs Baseline Dyspnea Index to evaluate dyspnea in chronic obstructive pulmonary disease. Int J Chron Obstruct Pulmon Dis. 2015; 10: 1663-1672.

[14] Rhee CK, Kim JW, Hwang YI, et al. Discrepancies between modified Medical Research Council dyspnea score and COPD assessment test score in patients with COPD. Int J Chron Obstruct Pulmon Dis. 2015; 10: 1623-1631.

[15] Mirza S, Clay RD, Koslow MA, et al. COPD guidelines: a review of the 2018 GOLD Report. Mayo Clin Proc. 2018; 93: 14881502 .

[16] Kim S, Oh J, Kim YI, et al. Differences in classification of COPD group using COPD assessment test (CAT) or modified Medical Research Council (mMRC) dyspnea scores: a cross-sectional analyses. BMC Pulm Med. 2013; 13: 35.

[17] Munari AB, Gulart AA, Dos Santos K, et al. Modified Medical Research Council dyspnea scale in GOLD classification better reflects physical activities of daily living. Respir Care 2018; 63: $77-85$.

[18] Cheng SL, Lin CH, Wang CC, et al. Comparison between COPD Assessment Test (CAT) and modified Medical Research Council (mMRC) dyspnea scores for evaluation of clinical symptoms, comorbidities and medical resources utilization in COPD patients. J Formos Med Assoc. 2019; 118: 429-435.

[19] Matera MG, Rogliani P, Cazzola M. Muscarinic receptor antagonists for the treatment of chronic obstructive pulmonary disease. Expert Opin Pharmacother. 2014; 15: 961-977.

[20] Ulrik CS. Once-daily glycopyrronium bromide (Seebri Breezhal$\mathrm{er}^{\circledR}$ ) for the treatment of chronic obstructive pulmonary disease (COPD). Expert Opin Pharmacother. 2015; 16: 2653-2659.

[21] D'Urzo AD, Kerwin EM, Chapman KR, et al. Safety of inhaled glycopyrronium in patients with COPD: a comprehensive analysis of clinical studies and post-marketing data. Int J Chron Obstruct Pulmon Dis. 2015; 10: 1599-1612.

(Speer Gábor dr.,

Biatorbágy, Mester u. 2., 2051 e-mail: vitamindspeer@gmail.com)

A cikk a Creative Commons Attribution 4.0 International License (https://creativecommons.org/licenses/by-nc/4.0/) feltételei szerint publikált Open Access közlemény. 